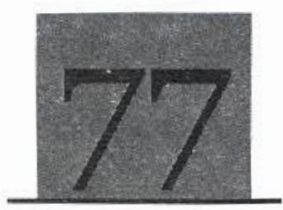

\title{
Fisheries survey in Cross River State, Nigeria
}

\author{
Holzlöhner, S. / F. Nwosu, F. M.
}

\begin{abstract}
The survey was performed in the Calabar Municipality, Calabar South, Odukpani, Akpabio and New Bakassi LGAs. Taken as indicator the mumber of canoes, the largest villages are situated in Akpabio and New Bakassi LGOs and the smallest in Calabar Municipality and Calabar South. The larger villages base economically apart from fishery on oil palm-dominated agriculture. There are villages where each men is fisher and farmer and others were these main professions are performed by different persons. In the larger villages are additionally operating carpenters (boat's builders), hunters, honey samplers and wood cutters. Nearly all women are engaged as fish traders and several as fish and shrimp pracessor (smoke-drying) and periwinkle samplerfprocessor. In the larger villages are three sizes of canves, small for two, medium for seven and large for 10-15 crew members. The smail canoes are mainly used for the gillnel fishery in drifi system on juvenile bonga (ekpui) in the dry season and on croaker and other demersal and semi-demersal species mainly in the rainy season and are common in all surveyed villages. They are also used for fisheries with trap, cast net and long line. With mediumsized cunoes is mainly operated the anchor net for catch of esiuarine shrimp and sometimes boat seine for actult bonga (ibat). The large canoes are engaged in the purse seine fishery on ibat in the near-coastal waters. In most of the larger villages is common expedition fishery: fishermen leave for up to several weeks and operate in the more productive outer estuary and near-coastal waters, mostly on adult boriga und estuarine shrimp; they produce smoke-dried products in their camps. The mean catch per boat per day is for the small canoes about $5 \mathrm{~kg}$, for the medium-sized $15 \mathrm{~kg}$ and for the large purse seine canoes more than $100 \mathrm{~kg}$. In Calabar Municipality and Calabar South LGAS all catches are fresh sold on own small markets at the landing site. In other LGAs is processing to smoke-dried products common. However, by using the mosily existing road connections to Calabar, also selling of fresh fish is performed. By estimation in the large villages, the monthly mean income per fisher family is N30,000, after paying for repairs of nets and outboard engine. Reporis on the daily income for fish processing and trading women included NO 500; the mean is probably by N100 or less.
\end{abstract}

\section{Introduction}

$\mathrm{F}$ rame survey is an important component of fishery investigations. It provides an inventory of basis characteristics of the fisheries industry, including number and distribution of fishing villages and landing sites, number of canoes or fishing units, number of fishermen among others (FAO, 1980). These statistical data are needed for stock assessment and regulation of the fisheries. Holzlōhner et al. (1997, 1998, 2002 and 2004) performed 1996-1999 a comprehensive fisheries and mangrove survey in the inner Cross River estuary and on the West coast of the outer estuary. The comparison of the mangrove with the socio-economic (fisheries) data permitted revealing conclusions. Such surveys are needed to derive scenarios for future development including the impact of and adaptations to the climate change.

The presented fisheries survey is a component of the Integrated Mangrove Forest Management Initiative (IMFORM), a 5-year socio-economic project of the NGO Concern Universal (CU), funded by the European Union with additional Irish Aid support. This project covers five LGAs in Cross River State, whose communities are living in and/or around the mangrove forest ecosystem. The area incorporates the Cross River State Mangrove Forest Reserve. The project is managed by CU in collaboration with a consortium of other Cross River State civil society groups and public sector stakeholders, including the Institute of Oceanography of University of Calabar. The project started on December 1, 2008.

\section{Materials and method}

Fisheries data and information as part of the socio-economic survey were sampled in Odukpani, Calabar South, Calabar Municipality, Akpabio and New Bakassi LGAs in 2009. The communities include Idua Inwang, Akwa Obutong, Edik Okon Idem and Ifiang Oyong in New Bakassi LGA, Okoho Ananwka, Esuk Atu, Esuk Anantigha, Duke Town, Cobham Town and Edibe-edibe in Calabar South/Municipality LGAs, Esuk Idebe Offong Umoh in Akpabuyo LGA as well as Ekpene Eki, Esuk 
Akim Akim and Mbombori in Odukpani LGA.

The main source was discussions with fisher groups in order to gather information on number of boats, catch objects, fishing gears and -methods, fish processing and -trade. We usually divided the survey team in two groups - for fishery and for the other aspects of the socio-economic survey. So far as we had access to the landings - often the landings were at night in accordance with the tidal cycle or the fishermen were on expedition fishery for weeks far off from their village - species identification and estimation of the quantity of catch were done and photographs of catches and fishing gears taken.

\section{Results and discussion}

Fishing boats and gears/methods: We observed during the survey, especially in the LGAs Calabar South and Calabar Municipality that many canoes were in a bad state due to age. During our socio-economic fisheries survey 1996-1999 (Holzlōhner et al, 1998 and 2004), we observed more dugouts than plank boats, at least relating to the typical small canoe for driftnet, long line and other passive fishcries. In our recent survey in 2009 , the canoes were mainly constructed from planks. The main reason for this change is doubtless the decreasing availability and increasing price of tree stems for constructing dugouts. By information in the village Idua Inwang, the price for a small plank canoe is now 7,000-30,000 N, depending on the quality of the planks.. The Chief of Duke Town asked us for assistance in improvement of the fisheries technique. Really needed is replacement of old and already decomposed boats. The number of boats was about 50 some time ago and has reduced to about 20 in the meantime (sec Table 1).

Table 1: Number of boats and main fishing gears in representative survey communities *

\begin{tabular}{|c|c|c|c|c|c|c|c|c|c|c|}
\hline $\begin{array}{l}\text { Name of } \\
\text { community }\end{array}$ & LGA & $\begin{array}{l}\text { Geographic } \\
\text { position }\end{array}$ & Boat nos. & $\begin{array}{l}\text { Gillnet as } \\
\text { driftnel }\end{array}$ & Trap & $\begin{array}{l}\text { Long- } \\
\text { line }\end{array}$ & $\begin{array}{l}\text { Anchor } \\
\text { net }\end{array}$ & $\begin{array}{l}\text { Cast } \\
\text { net }\end{array}$ & $\begin{array}{l}\text { Push } \\
\text { net }\end{array}$ & $\begin{array}{l}\text { Purse } \\
\text { seine }\end{array}$ \\
\hline Idua Inwang & New Bakassi & $\begin{array}{l}04^{\circ} 57.83 \mathrm{~N} \\
08^{\circ} 18.94 \mathrm{E}\end{array}$ & 100 & + & + & + & + & - & - & - \\
\hline Akwa Obutong & New Bakassi & $\begin{array}{l}04^{\circ} 48.37 \mathrm{~N} \\
08^{\circ} 32.16 \mathrm{E}\end{array}$ & 200 & + & + & + & + & + & + & + \\
\hline $\begin{array}{l}\text { Esuk Idebe } \\
\text { Offong Umoh }\end{array}$ & Akpa-buyo & $\begin{array}{l}04^{\circ} 50.58 \mathrm{~N} \\
08^{\circ} 25.53 \mathrm{E}\end{array}$ & 100 & + & + & + & + & + & + & + \\
\hline Okoho Ananwka & Calabar South & $\begin{array}{l}04^{2} 55.63 \mathrm{~N} \\
08^{2} 18.90 \mathrm{E}\end{array}$ & 10 & + & + & - & - & + & - & - \\
\hline Esuk Anantigha & Calabar South & $\begin{array}{l}04^{9} 54.91 \mathrm{~N} \\
08^{\circ} 19.37 \mathrm{E}\end{array}$ & 10 & + & + & - & - & + & - & - \\
\hline Cobham Town & Calabar South & $\begin{array}{l}04^{\circ} 55.82 \mathrm{~N} \\
08^{\circ} 19.10 \mathrm{E}\end{array}$ & 10 & + & + & - & - & + & - & - \\
\hline Edibedibe & Calabar South & $\begin{array}{l}04^{\circ} 56.16 \mathrm{~N} \\
08^{\circ} 18.52 \mathrm{E}\end{array}$ & 10 & + & + & - & - & + & - & - \\
\hline Duke Town & Calabar M'ty & $\begin{array}{l}04^{\circ} 56.49 \mathrm{~N} \\
08^{\circ} 20.53 \mathrm{E}\end{array}$ & 20 & + & + & - & - & + & - & - \\
\hline Esuk Atu & Calabar Mity & $\begin{array}{l}04^{\circ} 56.40 \mathrm{~N} \\
08^{\circ} 20.53 \mathrm{E}\end{array}$ & 8 & - & - & + & - & - & - & - \\
\hline
\end{tabular}

* Additionally was common in all surveyed villages the method of picking of periwinkle's by women

In the large villages in the LGAs New Bakassi and Akpabio, there are three sizes of canoes: small with two (2) crew members, medium-sized for seven (7) crew members and large with 10-15 crew members. The main fishing method for the small canoes is gillnetting on surface-near juvenile bonga (ekpai) as well as on croaker and other demersal and semi-demersal species; applied are also cast nets, traps and hook and line. The medium-sized boats operate mainly the anchor net for catch of estuarine shrimp (Nematopalaemon hastatus); also boat-seines are used for bonga and other fish species. The large boats are specialized in purse-scining on adult bonga (ibat) mainly in the coastal waters and in March/April additionally in the outer Cross River estuary. Expedition fishery is common with these large canoes. The fishermen remain for weeks outside the village nearer to the seasonal fishing grounds and slecp in guest houses/huts or in the boats. The catch-per-unit effort (cpue) catch/boat/day was estimated for the small canoes with $5 \mathrm{~kg}$, for the medium-sized canoes $15 \mathrm{~kg}$ and for the large purse seine canoes more than $100 \mathrm{~kg}$.

During our former fishing village survey (Holzlōhner et al.. 1997, 1998) was found out a significant correlation between the number of canoes and the number of fishermen in the village, with the equation: $y=3.89 x-19.53$, where $x$ - number of canoes and $y=$ number of fishermen based on 55 surveyed fishing villages/settlements. If each man is fisher and oil palm-dominated farmer as we found out in Isuk Idebe Offong Umoh in Akpabio LGA, then there is a way to estimate from the number of boats the entire population in the village using the family size from the household transect survey. In Akwa Obutong, New Bakassi LGA were the people specialized on one profession. There are about 700 fishers, 200 farmers, 50 carpenters (boat's builders), 30 hunters, 10 honey sampler, 5 wood cutters and about 500 fish traders (most of the village women).

In all surveyed villages was dominant the drift gill net fishery. During the season on juvenile bonga from November/ December to April/May, the canoes are utilized in good fishing periods for a fishing trip each tide, twice per day (two tides $=24$ hours + about 40 minutes); that means, the fishermen depart and return each day at another time. They work during the bonga season in shifts. Typically are also during the bonga season periods of bad catches or target fishery on bottom/semipelagic species because of market factors. Outside the bonga-season, usually is performed only one trip per day (two tidesperiod). Apart from paddle and sail, the periodically changing tidal currents are used to reach the catch site. During the catch process, only the tidal currents are used; that means the canoes and their driftnets in catch position drift with the tidal current 
to and back. Usually three to four sets, in dependence from the reached catches, are done during one trip. .

Fish processing/marketing: There is no fish processing (smoke-drying) in all surveyed villages in Calabar South and Calabar Municipality LGA. All catches are sold fresh on own small fish markets at the landing site. In the communities in New Bakassi and Akpabio LG $\Lambda$, processing by smoke-drying is present. However, in connection with road and boat transport possibilities to Calabar, a large part of the catch is sold fresh. For instance, fresh fish is brought from the villages in New Bakassi LGA per boat to the fish market in Ikang, from where fish traders transfer it per car to Calabar. Also the landing site at Atimbo bridge is used. The inhabitants of the large fishing village Akwa Obutong in Bakassi LGA bring fresh catch per bike to Ikang market. They asked for assistance to expand the bike path to a road for cars. The Fishermen during expedition fishery smoke-dry their catch in strange fishing villages or on suitable beach sites. Some women in Akwa Obutong are specialized on the processing of periwinkles and land snails. To maintain the quality, the sampled periwinkles or land snails are put in water for transport to the processing units in the village. After boiling, the women use needles to separate the snail bodies from the shells. The snail bodies are stored in water. Inside latest 24 hours, the processed periwinkles and land snails have to reach the final market. The shells are sold as component to produce concrete. Fish and shrimp smoke-drying needs a lot of fire wood which source are usually the mangrove trees. Although the large fishing viliages in Akpabio and New Bakassi LGA in comparison with the fishing villages at the West coast of the Cross River estuary (Akwa Ibom State) smoke-dry only a part of their catch and the mangrove forest is not so over-used by human activities, in the discussion with the fishermen came also the question why the ways to reach mangrove wood become longer. Also in the survey region is needed to reduce the utilization of mangrove trees and use the nipa palm; the old fruits are a good source for smoke-drying.

\section{Income:}

During the discussions in the large village Akwa Obutong near Ikang in New Bakassi LGA was mentioned an average income per fisher family and month of N40,000-N50,000. From this amount are used N10,000 20,000 for repair of nets and outboard engine. The cost for a medium-sized canoe is $\mathrm{N} 50,000$ and the shelf life at least 10 years. There remains about $\mathrm{N} 30,000$ per month and family for food, school fees, cte. Most fish processing and marketing activities are carried out by women, usually wives to the fishermen, that means most women in the communitics are engaged in this profession. The income per person is very low because on most landing days only a small percentage of the women get work. It was reported a daily income per woman of 0-500 Naira; the mean is probably by N100 or less. In combination with other sources we can assess that the mangrove fishing villages in our survey region like all over the world belong to the lowest category of income, cspecially in villages where there is no basis for agriculture as additional source.

\section{Conclusion}

Socioeconomic surveys including the fishery, combined with mangroves surveys should be performed at least in 10 years intervals. They are the basis to derive scenarios for future development including the impact of climate warming. In these scenarios are to integrate activities of men for protection and regulation of mangroves and estuarine/marine resources. A sound mangrove forest is in multiple ways the condition for the survival of the fishing villages and the welibeing of their inhabitants. Without mangroves many villages are erosion endangered in connection with the climate-warning induced sea level rise. There are research results that a sound mangrove forest can compensate the sea level rise. Mangroves are the source of fire wood in the villages for processing of fish and shrimps and cooking as well as for building purposes. Mangroves help also to transfer nutrients to the estuary and coastal waters which will maintain the fish and invertebrate production.

Nipa palm utilization will provide an additional source of income, especially for mangrove villages where is only fishery and no condition for oil palm dominated agriculture. Nipa palm utilization and mangrove planting which should be financed by the government will bring a lot of work, especially to jobless young people. In the survey region is incorporated the Cross River State Mangrove Forest Reserve, situated along the Cross River estuary between the mouth of Calabar and Great Kwa River. This Reserve should be managed by the relevant scientific rules. The propos ad Field Station of the Reserve (Holzlöhner, 2007) for enlightenment of the people, management the Reserve and as basis for research of students and scientist of Nigerian and foreign institutions should be established.

\section{REFERENCES:}

FAO.1980. The collection of catch and eftort statistics. FAO Fisheries Circular 730,63 pp.

Holzlöhner, S., Enin, U. I., Nwosu, F.M. 1997. Survey of the fishing villages in the inner Cross River estuary. $\$$ aroinar: Cross River Basin: Nature and culture. National Museum, Calabar, May 19-20, 16pp.

1998. Distribution of the fishing boats and gears in the inner Cross River Estuary, Southeast Nigeris. Anudual Conference of the Fisheries Society of Nigeria (FISON), Ibadan.

and E.R. Akpan. 2002. Mangrove mapping in the Cross River estuary. Afr. J. Envinan. Pollut. Health 1/2: $76-87$.

Holzlöhner, S., Nwosu, F. M., Enin, U.I. 2004. Fishing effort statistics of the artisanal fisheries of the Cross River estuary, Nigeria. Global Journal of Pure and Applied Sciences 10/7:249-256.

Holzlohner, S. 2007. Proposed Field Station in the Cross River Mangrove Reserve. Nipa palm control and mangrove restoration in southeast Nigeria. Prepared for U.N. Industrial Development Organization (UNIDO), 57pp. 